\title{
Os índios na História do Brasil no século XIX: da invisibilidade ao protagonismo ${ }^{1}$
}

\author{
Indians in the 19th century History of Brazil: \\ from invisibility to protagonism
}

Maria Regina Celestino de Almeida*

\section{RESUmo}

Com o objetivo de refletir sobre o lugar dos índios na história, considerando sua invisibilidade enquanto sujeitos históricos no século XIX e o protagonismo crescente revelado pela historiografia atual, o artigo analisa de forma conjunta questões relativas à política indigenista do Império, à cultura política indígena, ao nacionalismo e à etnicidade, enfocando a problemática das controvérsias e imprecisões sobre as classificações étnicas e os conflitos de terra nas antigas aldeias coloniais. Palavras-chave: política indigenista do Império; cultura política indígena; etnicidade.

\section{Abstract}

Aiming to reflect on the place of Indians in history, considering their invisibility as historical agents in the nineteenth century and their growing protagonism revealed by current historiography, this article jointly analyzes matters related to the Empire indigenous policy, the indigenous political culture, the nationalism and ethnicity, focusing on the issues of controversy and inaccuracy on ethnic classifications and land conflicts in the erstwhile colonial indigenous villages. Keywords: Empire indigenous policy; indigenous political culture; ethnicity.

A reflexão sobre o lugar dos índios na história, considerando sua invisibilidade enquanto sujeitos históricos no século XIX e o protagonismo crescente revelado pela historiografia atual implica, a meu ver, analisar de forma conjunta algumas questões que serão priorizadas neste artigo. Refiro-me à política indigenista do Império, à cultura política indígena, ao nacionalismo e à etnicidade, enfocando a problemática das controvérsias e imprecisões sobre as classificações étnicas e os conflitos de terra nas antigas aldeias coloniais.

Em 1992, no texto Política indigenista no século XIX, Manuela Carneiro

\footnotetext{
* Departamento de História, Universidade Federal Fluminense. Campus do Gragoatá, Bloco O, sala 503, 5o andar, Gragoatá. 24210-350 Niterói - RJ - Brasil. reginacelestino@uol.com.br
} 
da Cunha já abordava essas questões de forma entrelaçada, apontando para a falácia do discurso do desaparecimento dos índios. ${ }^{2}$ Vivos e atuantes nos sertões, vilas, aldeias e cidades do Brasil oitocentista, povos e indivíduos indígenas agiam e reagiam diferentemente às múltiplas formas de aplicação da política para eles traçada. Lutavam e continuavam reivindicando direitos na justiça na condição de índios, enquanto discursos políticos e intelectuais previam e, em muitos casos, já os consideravam desaparecidos, como resultado dos processos de civilização e mestiçagem. Esses discursos justificavam, conforme a política indigenista vigente, a extinção de antigas aldeias coloniais e de suas terras coletivas e, ao mesmo tempo, serviam à construção do nacionalismo, cuja proposta era criar a nação em moldes europeus, onde não havia lugar para pluralidades étnicas e culturais. A proposta assimilacionista, já lançada, desde meados do século XVIII, pelo marquês de Pombal, seria retomada com muito mais ênfase pelos políticos do Oitocentos. Apesar das divergências, predominava a proposta de incorporar os índios ao Império como cidadãos civilizados para servir ao novo Estado na condição de trabalhadores eficientes. Terra, trabalho e guerras associavam-se à questão indígena tão amplamente debatida no século XIX, como destacaram vários autores. Nas sessões do Instituto Histórico e Geográfico Brasileiro (IHGB), criado em 1838, os intelectuais debatiam o tema, comungavam com essas ideias e contribuíam para fortalecê-las, construindo histórias nas quais os índios eram valorizados em períodos anteriores, enquanto desconsideravam os grupos coevos presentes e atuantes nas sociedades nas quais se inseriam. Razões políticas, ideológicas e socioeconômicas articulavam-se, portanto, na construção de discursos e imagens sobre os índios que contribuíam para lhes retirar o papel de sujeitos históricos.

Em nossos dias, essas concepções vão sendo desmontadas. No palco da história, os índios vão, lentamente, passando da invisibilidade construída no século XIX para o protagonismo conquistado e restituído nos séculos XX e XXI por movimentos políticos e intelectuais nos quais eles próprios têm tido intensa participação. Desde a década de 1990, os historiadores no Brasil têm se voltado para o estudo dos índios, valorizando-os como sujeitos dos processos históricos por eles vivenciados. Com base em abordagens interdisciplinares, as pesquisas atuais centram o foco da análise nos próprios índios e identificam suas formas de compreensão e seus objetivos nas várias situações de contato por eles vividas, levando em conta os interesses e significados diversos 
das atuações políticas, socioeconômicas e culturais dos vários atores em contato.

Dentre as principais proposições teóricas e conceituais propiciadas pela aproximação da História com a Antropologia que têm contribuído para dar aos índios um novo lugar em nossa história, destaco a historicização de alguns conceitos básicos para se pensar sobre relações de contato. Entender cultura e etnicidade como produtos históricos, dinâmicos e flexíveis, que continuamente se constroem através das complexas relações sociais entre grupos e indivíduos em contextos históricos definidos, permite repensar a trajetória de inúmeros povos que por muito tempo foram considerados misturados e extintos. $\mathrm{Mu}$ danças culturais vivenciadas pelos índios ganham outras interpretações e passam a ser vistas não apenas como perda ou esvaziamento de uma cultura dita autêntica, mas em termos do seu dinamismo, mesmo em situações de contato extremamente violentas como foi o caso dos índios e dos colonizadores. $\mathrm{O}$ mesmo se pode dizer em relação às identidades indígenas que, transformadas e invisibilizadas, emergem hoje em conjunturas mais favoráveis, graças aos inúmeros processos de etnogênese. ${ }^{3}$ Tais processos evidenciam a falácia dos discursos de desaparecimento no século XIX. Alguns grupos, sobretudo no Nordeste, recuperam identidades indígenas com base nas antigas aldeias missionárias do período colonial que foram declaradas extintas pelo estado de mistura e civilização dos seus habitantes. Se, como afirmou Pacheco de Oliveira, esses processos não surgem do nada, é mister reconhecer que os índios nunca deixaram de existir, mas foram invisibilizados em conjunturas políticas e ideológicas desfavoráveis. ${ }^{4}$

As abordagens atuais procedem, sem dúvida, das novas perspectivas teórico-metodológicas da História e da Antropologia, mas decorrem também dos movimentos sociais e políticos protagonizados pelos próprios povos indígenas. Tal como em outras regiões da América e do mundo, os índios no Brasil, ao invés de desaparecerem como previsto por teorias assimilacionistas, chegaram ao final da década de 1980 crescendo e multiplicando-se. Os direitos indígenas garantidos pela Constituição de 1988 resultam, em grande parte, desses movimentos, ao mesmo tempo em que os incentivam. ${ }^{5}$ Em nossos dias, os povos indígenas estão, cada vez mais, conquistando novos espaços políticos, sociais e acadêmicos. Entre essas conquistas inclui-se um novo lugar na história do Brasil. 
As pesquisas atuais sobre os índios em contato com sociedades envolventes versam sobre os mais diversos temas em diferentes espaços e temporalidades, com significativa prioridade para o período colonial. Embora menos estudada, a presença e a atuação indígena na história do século XIX vem se tornando cada vez mais visível em pesquisas sobre diferentes temas. Dentre eles, ressalto a política indigenista do Império; as disputas por terras nas antigas aldeias coloniais; os discursos de desaparecimento dos índios; as guerras ofensivas contra os povos considerados selvagens, com destaque para os botocudos e os kaingangs; o indianismo brasileiro e as construções de imagens dos índios na literatura, nas artes e nos discursos de políticos, intelectuais e viajantes; o lugar dos índios na historiografia do século XIX; a exploração da mão de obra indígena em diversas regiões do Império; a incorporação dos índios dos sertões pelo estabelecimento de presídios militares e de novas missões religiosas, administradas sobretudo por capuchinhos; os inúmeros conflitos em regiões de fronteira, envolvendo índios dos sertões que negociavam com autoridades civis e militares; e a participação indígena nas forças militares, na guerra do Paraguai e nas rebeliões e movimentos políticos nas províncias do novo Império, entre outros. ${ }^{6}$

Essa listagem não esgota as possibilidades temáticas de estudos sobre os índios no Oitocentos e aponta para sua importância no período. No século XIX, o tema indígena estava na ordem do dia, como demonstram as discussões políticas na Assembleia Constituinte de 1823, na Assembleia Legislativa, nas câmaras municipais e nas sessões do Instituo Histórico e Geográfico Brasileiro (IHGB). Os intensos debates sobre como lidar com os índios no século XIX não deixam dúvidas sobre sua significativa presença nas províncias do Império.

\section{PolíticA INDIGENISTA E CULTURA POLÍTICA INDÍGENA No Oitocentos}

A política indigenista do Estado brasileiro incorporou e acentuou a proposta de promover a assimilação dos índios e extinguir antigas aldeias coloniais que havia sido introduzida pelas reformas pombalinas, em meados do século XVIII. Embora o Diretório dos Índios, legislação indigenista lançada naquele período, tenha sido extinto pela Carta Régia de 1798, muitas de suas diretrizes 
continuaram vigorando ao longo do século XIX. A ausência de uma política indigenista de caráter geral que só seria estabelecida em 1845, com o Regulamento das Missões, não impediu que a política assimilacionista fosse mantida e incentivada, dando sequência às propostas de Pombal. Porém, tal como no período anterior, diferentes procedimentos tinham que ser adotados para lidar com populações indígenas muito diversas, com diferentes níveis de inserção nas sociedades envolventes. Para os povos do sertão previa-se o aldeamento, mediante a criação de missões religiosas e presídios militares, com recurso às guerras justas quando se julgasse necessário; para os aldeados, já considerados civilizados, propunha-se a assimilação, com a distribuição de parcelas individuais de suas antigas terras coletivas que seriam extintas com as antigas aldeias. Guerras violentas, criação de novos aldeamentos e extinção de antigos foram práticas que coexistiram e se sucederam ao longo do século XIX. Todas visavam a um mesmo fim: a ocupação das terras indígenas e a transformação de seus habitantes em cidadãos e eficientes trabalhadores para servir ao novo Estado.

A chegada da Corte ao Rio de Janeiro, em 1808, e a declaração de guerra justa aos botocudos e posteriormente aos kaingangs não significaram profundas rupturas em relação a políticas anteriores. A distinção dos índios entre mansos e selvagens presentes na legislação desde o século XVI se acentuou, sem dúvida, com a declaração dessas guerras, porém o Príncipe Regente manteria a prática de zelar pela defesa dos índios aliados enquanto incentivava o combate aos inimigos. Na verdade, como destacou Langfur, a Carta Régia de 1808 viria apenas sancionar uma situação que já ocorria, pois as guerras contra os índios dos sertões de Minas Gerais nunca deixaram de ocorrer. ${ }^{7}$

Para os aldeados, a situação não se alterou muito, pois continuavam vendo no Rei, agora mais próximo, o justiceiro ao qual podiam recorrer diante das injustiças dos poderes locais. Não foram poucos os líderes indígenas que se deslocaram à Corte para pessoalmente pedir ao Rei a defesa de suas terras. Os índios aldeados séculos antes, em contato com o mundo colonial, haviam incorporado a cultura política do Antigo Regime e chegaram ao Oitocentos reivindicando antigos direitos que lhes haviam sido concedidos pela Coroa portuguesa por sua condição de súditos cristãos e fiéis servidores do rei. Aprenderam a valorizar acordos e negociações com autoridades e com o próprio rei, reivindicando mercês em troca de serviços prestados. ${ }^{8}$ 
No longo contato com os vários agentes sociais com os quais conviviam, os índios das aldeias desenvolveram suas próprias formas de compreensão sobre a nova realidade na qual se inseriam, sobre os direitos que lhes haviam sido concedidos e sobre as suas possibilidades de ação para obtê-los. Suas demandas fundamentavam-se basicamente em direitos assegurados pela legislação da Coroa Portuguesa por sua condição distinta da dos demais vassalos do Rei. Eram direitos que se ancoravam, portanto, na distinção étnica em relação aos demais vassalos. Assim, a afirmação da identidade indígena construída no interior das aldeias coloniais iria se tornar importante instrumento de reivindicação política por parte desses índios. ${ }^{9}$

Acredito que, ao chegarem ao século XIX, esses índios continuavam agindo em defesa de suas terras e aldeias de acordo com essa cultura política, pouco condizente com a do Estado nacional em construção, cujos valores se assentavam nos ideais de igualdade e liberdade com as limitações próprias do liberalismo brasileiro. Esses novos valores, que já se manifestavam desde o tempo da Ilustração, traduziam-se para os índios no fim de uma situação jurídica específica que, apesar dos imensos prejuízos, tais como sujeição ao trabalho compulsório e discriminação social, lhes garantia alguns direitos, dentre os quais a terra coletiva. Pela manutenção desses direitos, os índios das aldeias coloniais do Rio de Janeiro, do Nordeste, do Espírito Santo e provavelmente de muitas outras regiões do Brasil iriam se manter unidos até bem avançado o século XIX, desafiando a política assimilacionista que, desde meados do século XVIII, pretendia extingui-los como categoria, acabando com as distinções entre índios e não índios. ${ }^{10}$

Na documentação sobre conflitos de terra é possível constatar que, apesar do intenso processo de mestiçagem, os índios das antigas aldeias mantinham a vida comunitária e o sentimento de comunhão étnica que se manifestava sobretudo nas ações políticas para garantir os direitos que lhes haviam sido concedidos. Com base nas atuais proposições teóricas e conceituais da História e da Antropologia estudos recentes evidenciam que as identidades são plurais e as categorias étnicas são históricas e portadoras de significados que se alteram, conforme tempos, espaços e interesses dos agentes sociais, tanto dos classificadores quanto dos classificados. ${ }^{11}$ Isso nos permite constatar que os índios aldeados podem ter se tornado mestiços sem necessariamente terem deixado de ser índios. Desde meados do século XVIII e principalmente no decorrer do 
XIX, ser classificado de uma ou de outra forma implicava ganhos ou perdas de antigos direitos coletivos, o que sem dúvida incentivou as controvérsias e disputas por classificações étnicas tão visíveis na documentação desse período, sobretudo em conflitos de terra. A própria legislação favorecia esses embates, como se verá mais adiante. Por ora, cabe pensar sobre as concepções políticas e ideológicas do Oitocentos que contribuíam para reforçar a classificação dos aldeados como mestiços.

Após a Independência, o novo Estado imperial brasileiro viu-se diante do desafio de criar a nação e o povo brasileiro, até então, inexistentes. Era necessário criar no país uma unidade territorial, política e ideológica, gerando uma memória coletiva que unificasse as populações em torno de uma única identidade. A pluralidade étnica e cultural tão valorizada em nossos dias não tinha lugar nessa época, e a ideologia do novo Estado brasileiro baseava-se nos valores europeus de modernização, progresso e superioridade do homem branco. $^{12}$

Aos políticos e intelectuais do Brasil cabia homogeneizar populações extremamente diversas do ponto de vista étnico e cultural, unificando-as em torno de identidades e histórias comuns. Enfrentavam ainda o desafio de fazer frente às teorias de inferioridade do continente americano e de suas populações, em voga na Europa e com as quais eles, em grande parte, concordavam. A permanência da escravidão africana e a presença maciça de negros (escravos e libertos), índios e mestiços com as suas mais variadas denominações (pardos, caboclos, mulatos, cabras etc.) complicava a situação. Como construir uma identidade coletiva que os diferenciasse dos europeus, fortalecesse sua autoestima e ainda incorporasse os mais diversos grupos étnicos e sociais presentes nos seus territórios? Tal como ocorreu em outros países da América, a homogeneização de populações iria se dar no âmbito do discurso. Foi vitoriosa apenas no nível das ideias, pois vários grupos considerados extintos continuavam, de fato, existindo. ${ }^{13}$

A enorme diversidade de populações indígenas no território brasileiro dificultava não só a aplicação de uma política de caráter geral, como também a construção de uma única imagem de índio condizente com os ideais da nova nação. Do ponto de vista político, pregava-se o assimilacionismo, com procedimentos diversos, como já vinha ocorrendo desde o período pombalino. Do ponto de vista ideológico, discutia-se a possibilidade de tornar o índio símbolo 
nacional. O desafio era grande e as divergências, muitas. Afinal, os índios ocupavam terras, ameaçavam colonos, recusavam-se ao trabalho e lutavam para conservar suas aldeias. Como transformá-los em símbolo nacional se eram considerados inferiores e ameaças ao desenvolvimento e progresso econômico do Estado? Certamente, esses índios não serviam para simbolizar a nação, nem tampouco para compor o projeto de construção da memória e história coletivas do novo Estado.

Foi a imagem idealizada do índio que permitiu, no plano ideológico, transformá-lo em símbolo nacional. Essa imagem pouco teria a ver com os reais habitantes dos sertões e das aldeias do Império. Discursos e obras políticas, literárias, históricas, científicas e artísticas desse período caracterizaram-se pela idealização dos índios do passado, enquanto ignoravam ou demonizavam os grupos ou indivíduos indígenas ainda muito presentes no território brasileiro. Estes últimos, bastante vivos e atuantes no século XIX, eram presença constante nos artigos das revistas do Instituto Histórico e Geográfico Brasileiro (IHGB), nos Relatórios dos Presidentes de Província, na correspondência entre autoridades diversas e nas discussões da Assembleia Legislativa e das Câmaras Municipais. Essa documentação não deixa dúvidas sobre a atuação desses povos ao longo do século XIX, atuação essa que, como em períodos anteriores, influenciava os rumos das políticas para eles traçadas.

Discutia-se essencialmente se os índios deviam ser integrados de forma pacífica ou violenta. As concepções políticas e ideológicas sobre os índios se associavam e eram fundamentalmente influenciadas pelas realidades econômico-sociais do novo Estado. Como destacou David Treece, as representações romantizadas do índio que apareceram de diferentes formas na literatura, na música e na pintura não estavam descoladas da realidade política e social do período (Treece, 2008). Eram, sem dúvida, construções idealizadas, porém estavam ancoradas nos contextos históricos em que foram elaboradas. Os intelectuais e artistas por elas responsáveis não viviam, absolutamente, alheios às discussões políticas e sociais sobre os índios. Na maioria das vezes, envolviam-se nelas diretamente pelas funções políticas exercidas e quando não o faziam, suas obras, de um modo geral, influenciavam e eram influenciadas pelas realidades que vivenciavam. Os intelectuais responsáveis pela construção das imagens sobre os índios, bem como os viajantes, cujas descrições contribuíam para reforçá-las, comungavam, grosso modo, com as ideias de assimilar 
os índios e transformá-los em eficientes cidadãos do novo Império. Seus discursos e representações eram coerentes com a política indigenista do século XIX.

Embora não fossem novidade do século XIX, as discussões sobre práticas de brandura ou de violência para lidar com os índios foram foco de intensos debates nesse período. Sem abordar essa complexa discussão, importa ressaltar a predominância das teorias racistas e discriminatórias entre políticos e intelectuais que, grosso modo, concordavam com a ideia da inferioridade dos índios. Divergiam, no entanto, sobre sua potencialidade para alcançar a civilização, questão que fundamentava as discussões sobre como incorporá-los. José Bonifácio de Andrada e Silva e Francisco Adolfo de Varnhagen destacaram-se nesse debate, e, embora ambos concordassem com a ideia de inferioridade dos índios, posicionavam-se em campos opostos. O primeiro defendia sua humanidade e capacidade de civilizar-se, propondo a integração branda, ao passo que Varnhagen afirmava a bestialidade dos índios que, no seu entender, só poderiam ser incorporados e submetidos por meio da guerra e do extermínio. $^{14}$

Na política oficial do Império iria predominar a proposta de Bonifácio. Seu projeto defendia a política assimilacionista que visava incorporá-los como cidadãos e, embora condenasse o uso da força, reconhecia sua necessidade em algumas circunstâncias. Apesar de aprovado na Assembleia Constituinte, em 1823, não chegou à prática, e a Constituição de 1824 sequer mencionou a questão indígena que se tornou competência das Assembleias Legislativas Provinciais, tendo prevalecido o interesse das oligarquias locais. A política indigenista do Império caracterizou-se, então, pela descentralização, e os índios, ainda divididos nas categorias de mansos e bravos, tinham, de acordo com Carneiro da Cunha, a possibilidade de escolher entre a 'civilização' e o 'extermínio', ou seja, entre uma submissão branda e uma violenta. Várias leis de caráter local continuariam sendo estabelecidas em prejuízo dos índios, porém, no discurso oficial, prevalecia a recomendação para o uso de meios brandos e persuasivos, reservando-se a violência para os que se recusassem a colaborar.

Para as populações indígenas das aldeias, em contato com a sociedade colonial por um período de três séculos, o desafio era continuar existindo como comunidades no momento em que o novo Estado acentuava a política assimilacionista que visava extingui-los como etnias diferenciadas. A legislação 
indigenista do século XIX incentivava o processo de individualização das terras indígenas com um discurso humanitário que visava integrar os índios em igualdade de condições, transformando-os em cidadãos. Afinal, os ideais de civilização e progresso característicos do novo Estado não comportavam a ideia de índios, nem de vida comunitária. O objetivo era, sem dúvida, extinguir as aldeias, mas de acordo com a lei e respeitando-se os direitos dos índios, enquanto eles fossem considerados como tais.

As propostas assimilacionistas construíam-se de forma a ressaltar as vantagens que a nova condição de cidadão daria aos índios. Tais propostas eram reforçadas pelas construções dos intelectuais que idealizavam os índios do passado enquanto viam seus contemporâneos como degradados. A solução ideal para eles era, de acordo com esses discursos, integrarem-se à sociedade nacional, tornarem-se cidadãos e terem acesso a propriedades individuais. Valores caros aos índios, como vida comunitária e reciprocidade, eram vistos como negativos e obstáculos ao progresso.

Quanto à legislação sobre terras, o Regulamento das Missões manteve os direitos dos índios nas aldeias, decretando ser obrigação do Diretor Geral designar terras para plantações comuns, para plantações particulares dos índios e para os arrendamentos. Porém, o regulamento seguia as orientações assimilacionistas predominantes. Sobre as aldeias, decretava em seu artigo $1^{\circ} \S 2$ que se informasse ao "Governo Imperial sobre a conveniência de sua conservação, ou remoção, ou reunião de duas, ou mais, em uma só”. ${ }^{15}$ A Lei de Terras de 1850 também estabelecia uma reserva de terras para a colonização de indígenas, porém foi o regulamento de 1854 que veio explicitar com mais nitidez a política assimilacionista do Império: reservava as terras para os índios em usufruto, afirmando que "não poderão ser alienadas, enquanto o governo Imperial, por ato especial, não lhes conceder o pleno gozo delas, por assim o permitir o seu estado de civilização" (Carneiro da Cunha, 1992b, p.223).

Em 1861, a questão dos índios passou à esfera do Ministério da Agricultura e Obras Públicas, o que aponta para a associação entre a política indigenista e questões agrárias. Em várias regiões do Império, sobretudo a partir da segunda metade do século XIX, a questão indígena tornava-se basicamente uma questão de terras, como destacou Manuela Carneiro da Cunha. O Regulamento das Missões de 1845 e a Lei de Terras de 1850, complementada com o regulamento de 1854, reafirmaram o conteúdo do Diretório em dois 
importantes aspectos: incentivavam a proposta assimilacionista e continuavam garantindo o direito dos índios às terras coletivas enquanto eles não atingissem o chamado estado de civilização. Isso dava aos índios das aldeias possibilidades de continuarem reivindicando, por intermédio da lei, os direitos que lhes haviam sido garantidos. Essas reivindicações, deve-se lembrar, baseavam-se na afirmação da identidade indígena. Ser ou não ser considerado índio implicava, como visto, ganhar ou perder direitos, sobretudo à terra coletiva, razão pela qual as controvérsias e disputas em torno das classificações étnicas iriam se tornar muito mais acentuadas ao longo do século XIX.

\section{ClassificaÇões ÉtNiCAS E CONFLITOS DE TERRA NAS ANTIGAS ALDEIAS COLONIAIS}

No decorrer do século XIX, incentivados pela política assimilacionista da Coroa portuguesa e depois do Império, as câmaras municipais e os moradores intensificavam suas investidas para apoderar-se das terras e dos rendimentos coletivos das aldeias. Estas eram descritas como decadentes e miseráveis, mas continuavam despertando conflitos, pois os índios insistiam em preservá-las. Misturados e transformados no interior das aldeias, os aldeados, talvez, dificilmente pudessem se distinguir de seus vizinhos não índios por sinais diacríticos, laços consanguíneos, caracteres físicos ou traços culturais nítidos, porém não abandonaram suas identidades indígenas. Se, de acordo com Cohen, os grupos têm interesse em permanecer distintos enquanto condições políticas e econômicas estão ligadas a essa distinção, essa parece ter sido uma forte razão para sua resistência à política assimilacionista, que os levou a manter, para usar a expressão de Roberto C. de Oliveira, sua 'identidade contrastiva' em relação aos moradores com os quais interagiam e até dividiam o mesmo espaço. ${ }^{16}$ As contendas nessa época se faziam principalmente pela manutenção do patrimônio, ao qual tinham direito como grupo: as terras e os rendimentos das aldeias.

Foi principalmente em torno da ação política comum pela manutenção desses direitos que essas identidades, a meu ver, se mantiveram e até se fortaleceram nesse período, contra as pressões que se faziam no sentido de reconhecê-los como mestiços. Unificava-os a ideia de pertencer à aldeia e o compartilhamento de um passado comum que remontava à fundação da aldeia e 
à aliança com os portugueses, bem como a ação política coletiva em busca dos direitos que lhes tinham sido dados. ${ }^{17}$ Apesar das misturas, afirmavam, como informam os documentos, a identidade indígena que naquele mundo conturbado lhes garantia a vida comunitária e a terra coletiva. Mantinham o sentimento de comunhão étnica, desenvolvido na experiência comum do processo de territorialização nas aldeias coloniais, no sentido dado por Pacheco de Oliveira (1999). Assim, podiam identificar-se ou serem identificados como índios ou como mestiços, conforme circunstâncias e interesses. Mestiços ou índios, os aldeados chegaram ao final do século XVIII e ao XIX agindo com base em uma cultura política que, originária de um processo de mestiçagem, fundamentava-se na identidade indígena construída nas aldeias coloniais.

Isso pode ser verificado em estudos recentes sobre o Rio de Janeiro, o Espírito Santo e várias províncias do Nordeste. A razão principal que os unia em torno do objetivo de manter as antigas aldeias decorria, a meu ver, do fato de elas ainda constituírem, nesse período, espaço de proteção. Ali, ainda tinham garantidos, além da terra e de seus rendimentos, a vida em comunidade. Numa ordem social rigidamente hierárquica e escravocrata, tais direitos deviam ser muito atraentes. Apesar de transformados, misturados e vivendo em aldeias pobres e decadentes como afirmam muitos relatos, os índios aldeados mantiveram-se como tais durante pelo menos mais um século após as reformas de Pombal. Lutavam (eventualmente com apoio de algumas autoridades civis e eclesiásticas), juridicamente, para manter suas aldeias contra a forte pressão que se fazia no sentido de extingui-las.

Observa-se, então, que controvérsias e contradições sobre classificações étnicas dos índios nas categorias de índios ou misturados (mestiços), já presentes na documentação e em disputas por terras nas aldeias do Rio de Janeiro desde o século XVIII, iriam se tornar muito mais frequentes. Essas controvérsias envolviam direitos, pois o fato de ser índio permitia manter as terras coletivas e o patrimônio das aldeias, ao passo que ser mestiço significava perdê-los. Os argumentos dos atores para garantir ou negar direitos aos índios faziam-se, cada vez mais, em torno das classificações étnicas. Para justificar a extinção das aldeias, construía-se o discurso da mistura e do desaparecimento dos índios. Estes últimos, por sua vez, respondiam reivindicando direitos com base na identidade indígena construída no processo da colonização. Para os índios, a igualdade significava o fim de um status jurídico-político específico, 
graças ao qual distinguiam-se dos demais segmentos sociais e que, apesar dos limites, dava-lhes proteção e alguns direitos especiais, sobretudo à terra coletiva. Por essa razão, disputas por classificações étnicas podem ser entendidas como disputas políticas e sociais, como destacou Guillaume Boccara (2000).

Na segunda metade do século XIX, a intensa correspondência oficial entre autoridades do governo central, das províncias e dos municípios é reveladora da preocupação do Estado em obter o máximo de informações possíveis sobre os aldeamentos e os índios com o nítido objetivo de dar cumprimento à política assimilacionista, a ser implementada conforme as situações específicas de cada região. Não é de estranhar, portanto, que o conteúdo desses documentos insistisse tanto na decadência, miserabilidade e diminuição dos índios e suas aldeias.

Em 1850, carta circular aos Presidentes de Província ordenava-lhes o envio de informações

sobre os aldeamentos dos índios, declarando as alterações que tenham tido tanto a respeito da população como dos ramos da agricultura, indústria e comércio a que se dedicam com designação das causas que concorrem para a decadência dos mesmos aldeamentos, os meios para as remover, bem como os que parecerem próprios para chamar os selvagens a vida social... ${ }^{18}$

No mesmo ano, outra circular aos Presidentes de Província tratava do

destino que se deve dar às terras dos índios, visto não os haverem aldeados, e não ter a elas aplicação o Regulamento n. 426 de 24 de junho de 1845, que ... deve continuar as providências adotadas para incorporação aos próprios nacionais de todas aquelas terras que não estiverem ocupadas, as quais se devem considerar devolutas... (idem)

O conteúdo desses documentos evidencia o interesse do Estado em obter informações para justificar a extinção das aldeias, de acordo com a lei. Cabe lembrar que o Regulamento de 1845 decretara o direito dos índios à terra nas aldeias, considerando, no entanto, a possibilidade de extingui-las conforme seu estado de decadência, e o regulamento de 1854 estabelecera para os índios o usufruto temporário das terras, até que atingissem o 'estado de civilização', quando o governo imperial poderia incluí-los no pleno gozo dos direitos de todos os cidadãos. Isso significava acabar com seus direitos às terras 
coletivas.

No Rio de Janeiro, dando cumprimento às ordens do governo central, o presidente da Província estabeleceu significativa correspondência com as autoridades municipais, sobretudo juízes de órfãos, para saber se "existem povoações de índios, qual o estado de seu aldeamento, nação e patrimônio...". ${ }^{19}$ Pediam-se também informações sobre as terras das aldeias e suas medições, bem como sobre os possíveis serviços que os índios porventura prestassem aos moradores e/ou autoridades. Os documentos não deixam dúvidas sobre o interesse das autoridades em extinguir as aldeias. Para isso era preciso constatar seu desaparecimento ou estado de decadência, o que se revela em muitos relatos com referência a antigas aldeias abandonadas muitos anos antes por índios que, de acordo com os informes, viviam dispersos, vagando pelos sertões. Contrariando esses documentos, os índios reivindicavam direitos.

A aldeia de São Lourenço, a primeira estabelecida no Rio de Janeiro, foi extinta em 1866. Desde 1861, a Câmara Municipal de Niterói solicitava à Presidência da Província a incorporação dos terrenos da sesmaria da aldeia, alegando serem estes os melhores terrenos do município e que pouco rendiam, sob a administração de pessoas desinteressadas. Alegavam a importância desses rendimentos para cobrir despesas da cidade, cujos recursos eram escassos, e que os "indígenas com o andar dos tempos, têm desaparecido, e mesmo os muito poucos que existem, não são puros" ${ }^{20}$ Em outubro de 1865 foi dada autorização para que o Presidente da Província extinguisse a aldeia, sob a alegação de "que os poucos índios ali existentes com esta denominação se acham nas circunstâncias de entrarem no gozo dos direitos comuns a todos os brasileiros...". ${ }^{21}$ No ano seguinte, documento, provavelmente da Câmara Municipal negava a pretensão de "intitulados índios, que solicitam a continuação de mensalidades outrora arbitradas" afirmando não ser possível atendê-los "pois o Aviso de 31 de outubro havia extinguido o mencionado aldeamento", tendo feito desaparecer a "entidade Índios e proveu ao bem estar dos que com essa denominação ainda ali existiam". ${ }^{22}$

O Aviso declarou, portanto, o desaparecimento não só da aldeia, mas também dos índios, que apesar de terem sua presença ali reconhecida, ao reivindicarem direitos um ano depois, eram declarados inexistentes pelas autoridades locais. Outros exemplos poderiam ser citados confirmando que o discurso das autoridades construía-se conforme seus interesses em ter acesso às 
terras das aldeias, porém respeitando as exigências da legislação. Assim, aos índios nas aldeias ou em terrenos das aldeias as autoridades informantes acrescentavam advérbios e adjetivos como 'poucos', 'diminutos', 'misturados' ou 'civilizados' e os tornavam inexistentes, justificando a extinção das aldeias.

Processo semelhante foi observado por Edson Silva em várias províncias do Nordeste. A rica documentação analisada pelo autor apresenta as mesmas contradições entre as afirmativas de que os índios estariam confundidos com a massa da população e desaparecidos e os documentos dos próprios índios que continuavam reivindicando direitos. Enquanto os relatos da Presidência da Província afirmavam, na década de 1850, a inexistência de aldeamentos indígenas no Ceará, documentação posterior registrava solicitações dos índios por seus direitos. A petição dos índios da aldeia de São Miguel do Una (em Barreiros, Pernambuco) é ilustrativa a esse respeito. Pediam providências por se sentirem perseguidos, pois, segundo eles, depois de terem "recebido suas terras por doação confirmada em Carta Régia de 1698, como recompensa pela participação ao lado das tropas legais nos combates ao Quilombo dos Palmares...", elas haviam sido invadidas por outros conquistadores que "circulando a aldeia por todos os lados, cada hum tratou de edificar engenhos, dizendo-se que na Aldeia não existiam mais índios da raça primitiva" (Silva, 1996, p.23). Muitos outros exemplos semelhantes foram apontados pelo autor.

No Espírito Santo, segundo Vânia Losada Moreira, conflitos por terras entre índios de antigas aldeias e câmaras municipais também envolviam discussões sobre classificações étnicas. Os índios da vila de Nova Almeida (antiga aldeia dos Reis Magos), espoliados e enfrentando contínuas usurpações territoriais por parte de moradores e câmaras municipais, conseguiram por lei o direito de registrar suas terras e livrar-se da tutela, mantendo a identidade indígena (Moreira, 2002).

\section{CONSIDERAÇÕES FINAIS}

O processo de extinção das antigas aldeias coloniais envolveu, em várias regiões, o apagamento das identidades indígenas por diferentes autoridades e moradores. Esse apagamento era contrariado pela ação política dos próprios índios que, com requerimentos e petições, desafiavam esses discursos afirmando a identidade indígena e seus antigos direitos obtidos pelos acordos com a 
Coroa Portuguesa. As disputas e controvérsias sobre classificações étnicas, já presentes na documentação desde o século XVIII, tornaram-se muito mais acentuadas no decorrer do XIX, na medida em que eram cada vez mais acionadas pelos grupos em disputa para fazer valer seus interesses. As aldeias acabariam extintas, porém, após processos longos, repletos de avanços e recuos. Nesses processos, os índios tiveram participação importante, contribuindo, me parece, para retardá-los.

Do século XIX aos nossos dias, inúmeros povos indígenas deixaram de existir como etnias diferenciadas. Porém, muitos deles estão ressurgindo hoje mediante processos de etnogênese pelos quais reafirmam suas identidades indígenas e reivindicam direitos, sobretudo à terra coletiva, como se observa no Nordeste e no Espírito Santo. Outros, contudo, desapareceram, como foi o caso dos aldeados do Rio de Janeiro. É instigante, no entanto, vê-los também reaparecer, de certa forma, não só nas histórias que vêm sendo reconstruídas, como também nas memórias de seus descendentes. A aldeia de São Lourenço foi, como visto, extinta em 1866. Contudo, no bairro do mesmo nome, em Niterói, José Luiz de Arariboia Cardoso e Gilda Rodrigues, em 1930 e 2003, respectivamente, assumiram sua descendência dos índios da aldeia e do próprio Arariboia, seu primeiro capitão-mor. ${ }^{23} \mathrm{~A}$ história oral ainda pode ter muito a revelar sobre a memória dos antigos aldeamentos.

Os processos de etnogênese dos nossos dias, somados a essas e outras histórias sobre muitos índios desaparecidos, apontam para a importância de se repensar a presença e a atuação indígena na história do século XIX. No caminho inverso da historiografia do Oitocentos, historiadores, antropólogos e os próprios índios estão, hoje, ainda que lentamente, conduzindo os índios da invisibilidade ao protagonismo histórico. Com isso, contribuem para compreensões mais amplas e complexas sobre as histórias regionais e sobre a própria história do Brasil.

\section{NOTAS}

${ }^{1} \mathrm{O}$ conteúdo deste artigo encontra-se, em parte, publicado em textos anteriores, sobretudo em: ALMEIDA, M. Regina Celestino de. Etnicidade e Nacionalismo no Século XIX. In: Os índios na História do Brasil. Rio de Janeiro: Ed. FGV, 2010. p.135-167. 
${ }^{2}$ CARNEIRO DA CUNHA, Manuela. Política indigenista no século XIX. In: (Org.). História dos índios no Brasil. São Paulo: Companhia das Letras, 1992a. p.133-154.

${ }^{3}$ Sobre essas questões, ver, entre outros: THOMPSON, E. P. Miséria da teoria. Rio de Janeiro: Zahar, 1981. 231p.; MINTZ, Sidney. Cultura: uma visão antropológica. Tempo, Niterói (RJ): Eduff, v.14, n.28, p.223-237, 2010; BARTH, Fredrik. Os grupos étnicos e suas fronteiras. In: LASK, T. (Ed.). O guru, o iniciador e outras variações antropológicas. Rio de Janeiro: Contra Capa, 2000. p.25-67; HILL, Jonathan. (Org.). History, power and identity: ethnogenesis in the Americas, 1492-1992. Iowa City: University of Iowa Press, 1996. 277p.; BOCCARA, Guillaume. Mundos nuevos en las fronteras del Nuevo Mundo: relectura de los procesos coloniales de etnogénesis, etnificacón y mestizaje en tiempos de globalización. Mundo Nuevo Nuevos Mundos, Revista Eletrônica, Paris, 2000. Disponível em: www.ehess. fr/cerma.Revuedebates.htm.

${ }^{4}$ PACHECO DE OLIVEIRA, João (Org.). A viagem da volta: etnicidade, política e reelaboração cultural no Nordeste indígena. Rio de Janeiro: Contra Capa, 1999. 350p.; PACHECO DE OLIVEIRA, João (Org.). A presença indígena no Nordeste: processos de territorialização, modos de reconhecimento e regimes de memória. Rio de Janeiro: Contra Capa, 2011. 714p.

${ }^{5}$ Ao garantir aos índios, pela primeira vez, o direito à diferença, assegurando-lhes educação, saúde e, sobretudo, terra coletiva, a Constituição de 1988 sancionou uma situação de fato, pois os próprios índios afirmavam suas identidades distintas e reivindicavam direitos. Ao mesmo tempo, incentivou a proliferação de movimentos de etnogênese, através dos quais vários povos considerados misturados passaram a afirmar suas identidades indígenas, sobretudo na região Nordeste. Sobre isso ver: OLIVEIRA, 1999; MONTEIRO, John M. O desafio da História Indígena no Brasil. In: SILVA, Aracy Lopes da; GRUPIONI, Luís D. Benzi (Org.). A temática indígena na escola: novos subsídios para professores de $1^{\circ}$ e $2^{\circ}$ graus. Brasília: MEC/Mari/Unesco, p.221-228, 1995; MONTEIRO, John M. Tupis, tapuias e historiadores: estudos de História Indígena e do Indigenismo. Tese (Livre Docência) IFCH, Unicamp. Campinas (SP), 2001; BOCCARA, 2000.

${ }^{6}$ CARNEIRO DA CUNHA, Manuela. 1992a; CARNEIRO DA CUNHA, Manuela. Legislação indigenista no século XIX: uma Compilação (1808-1889). São Paulo: Edusp, 1992b. 363p.; SAMPAIO, Patrícia. Política Indigenista no Brasil Imperial. In: GRINBERG, Keila; SALLES, Ricardo. O Brasil Imperial. Rio de Janeiro: Civilização Brasileira, 2009. v.1, p.177206; SPOSITO, Fernanda. Nem cidadãos, nem brasileiros: indígenas na formação do Estado nacional brasileiro e conflitos na província de São Paulo (1822-1845). São Paulo: Alameda, 2012. 291p.; PACHECO DE OLIVEIRA, João (Org.) A fabricação social da mistura. In: , 2011, p.295-510; SILVA, Edson. 'Confundidos com a massa da População': o esbulho das terras indígenas no Nordeste no século XIX. Revista do Arquivo Público de Pernambuco, Recife, n.46, v.42, p.17-29, 1996; ALMEIDA, M. Regina Celestino de. Política indigenista e etnicidade: estratégias indígenas no processo de extinção das aldeias do Rio de Janeiro - século XIX. Anuario del IEHS, Tandil: Instituto de Estudios Históricos-Sociales, p.219-233, 2007; MOREIRA, Vânia Losada. Nem selvagens nem cidadãos: os índios da Vila de Nova Almeida e a usurpação de suas terras durante o século XIX. Dimensões, Vitória: 
Universidade Federal do Espírito Santo, n.14, p.151-167, 2002; MATTOS, Izabel Missagia de. Civilização e revolta: os botocudos e a catequese na Província de Minas. Bauru (SP): Edusc, 2004. 491p.; MOTA, Lúcio Tadeu. As Guerras dos Índios Kaingang: a história épica dos índios Kaingang no Paraná, 1769-1924. Maringá (PR): Ed. UEM, 1994; TREECE, David. Exilados, aliados, rebeldes: o movimento indianista, a política indigenista e o Estado-nação imperial. São Paulo: Edusp, 2008. 351p.; KODAMA, Kaori. Os índios no Império do Brasil: a etnografia do IHGB entre as décadas de 1840 e 1860. Rio de Janeiro: Ed. Fiocruz; São Paulo: Edusp, 2009. 332p.; TURIM, Rodrigo. A 'Obscura História Indígena': o discurso etnográfico no IHGB (1840-1870). In: GUIMARÃES, Manoel Luiz S. (Org.). Estudos sobre a escrita da História. Rio de Janeiro: 7Letras, 2006. p.86-113; GUIMARÃES, Manoel L. Salgado. Nação e civilização nos Trópicos: o Instituto Histórico e Geográfico Brasileiro e o projeto de uma História Nacional. Estudos Históricos, Rio de Janeiro: Ed. Revista dos Tribunais, n.1, p.5-27, 1988; CARVALHO, Marcus J. M. de. A Mata Atlântica: sertões de Pernambuco e Alagoas, séculos XVII-XIX. Clio, Revista de Pesquisa Histórica, Recife: UFPE, v.25, n.2, p.249-266, 2007; KARASCH, Mary. Catequese e cativeiro: política indigenista em Goiás, 1780-1889. In: CARNEIRO DA CUNHA, 1992a, p.397-412; AMOROSO, Marta Rosa. Catequese e evasão: etnografia do Aldeamento Indígena São Pedro de Alcântara - Paraná (1855-1895). Tese (Doutorado) - Departamento de Antropologia, USP. São Paulo, 1998. 282p. Para uma visão abrangente da produção historiográfica sobre os índios nas últimas décadas, ver o excelente site de John Manuel Monteiro: www.ifch.unicamp.br/ihb/.

${ }^{7}$ LANGFUR, Hal. Uncertain refuge frontier formation and the origin of the Botocudo War in late Colonial Brazil. Hispanic American Historical Review, v.82, n.2, p.215-256, 2002.

${ }^{8}$ ALMEIDA, M. Regina Celestino de. Metamorfoses indígenas: identidade e cultura nas aldeias coloniais do Rio de Janeiro. Rio de Janeiro: Arquivo Nacional, 2003. 301p.

${ }^{9}$ ALMEIDA, M. Regina Celestino de. Quando é preciso ser índio: identidade étnica como força política nas aldeias do Rio de Janeiro. In: REIS, Daniel A. et al. (Org.). Tradições e modernidades. Rio de Janeiro: Ed. FGV, 2010. p.47-60.

${ }^{10}$ ALMEIDA, 2007; CARNEIRO DA CUNHA, 1992a; MOREIRA, 2002; SILVA, 1996; SILVA, Isabelle Braz Peixoto. O Relatório Provincial de 1863 e a expropriação das terras indígenas. In: PACHECO DE OLIVEIRA, 2011, p.327-345; DANTAS, Mariana. Estratégias indígenas: dinâmica social e relações interétnicas no aldeamento de Ipanema no final do século XIX. In: PACHECO DE OLIVEIRA, 2011, p.413-445.

${ }^{11}$ BOCCARA, 2000; DE JONG, Ingrid; RODRIGUES, Lorena. Introducción. Dossier Mestizaje, Etnogénesis y Frontera. Memoria Americana, Buenos Aires: Universidad de Buenos Aires, n.13, p.9-19, 2005; CADENA, Marisol. Are Mestizos Hybrids? The Conceptual Politics of. Andean Identities. Journal of Latin American Studies, Cambridge: Cambridge University Press, n.37, p.259-284, 2005; ALMEIDA, M. R. Celestino de. Índios e mestiços no Rio de Janeiro: significados plurais e cambiantes. Memoria Americana, Buenos Aires: Universidad de Buenos Aires, v.16, p.19-40, 2008; MATTOS, Hebe. Escravidão e cidadania no Brasil Monárquico. Rio de Janeiro: Zahar, 2000.

${ }^{12}$ MOREIRA NETO, Carlos de Araujo. Índios da Amazônia: de maioria a minoria (1750- 
1850). Petrópolis (RJ): Vozes, 1988. 348p.; QUIJADA, Mónica. El paradigma de la homogeneidad. In: QUIJADA, Mónica; BERNAND, Carmen; SCHNEIDER, Arnd. Homogeneidad y nación con un estudio de caso: Argentina, Siglos XIX y XX. Madrid: CSIC, 2000. p.7-57; GUIMARÃES, 1988.

${ }^{13}$ QUIJADA, Mónica, 2000; MALLON, Florencia. Peasant and nation: the making of postcolonial México and Peru. California: University of California Press, 1995.

${ }^{14}$ Sobre teorias raciais e discriminatórias, ver: SCHWARCZ, Lilia Moritz. O espetáculo das raças: cientistas, instituições e questão racial no Brasil - 1870-1930. São Paulo: Companhia das Letras, 2001. 287p.; sobre as propostas de Varnhagen e Bonifácio, ver: TURIM, 2006; GUIMARÃES, 1998; BOEHRER, G. C. A. (Ed.). Apontamento para a civilização dos índios bárbaros do Reino do Brasil por José Bonifácio de Andrada e Silva. Lisboa: Agência Geral do Ultramar, 1966. 93p.; DOLHNIKOFF, Miriam (Org.). José Bonifácio de Andrada e Silva: Projetos para o Brasil. São Paulo: Companhia das Letras, 1998. 371p.; CARNEIRO DA CUNHA, 1992a.

${ }^{15}$ Decreto ${ }^{\circ} 426$, de 24 jul. 1845. Regulamento acerca das Missões de catechese e civilização dos Índios. Apud BEOZZO, José Oscar. Leis e Regimentos das Missões: política indigenista no Brasil. São Paulo: Loyola, 1983. p.169.

${ }^{16}$ COHEN, Abner. Organizações invisíveis: alguns estudos de caso. In: O homem bidimensional: a antropologia do poder e o simbolismo em sociedades complexas. Rio de Janeiro: Zahar, 1978. p.115-147; OLIVEIRA, Roberto Cardoso de. Identidade étnica, identificação e manipulação. In: . Identidade, etnia e estrutura social. São Paulo: Pioneira, 1976. p.131.

${ }^{17}$ ALMEIDA, 2003; WEBER, M. Relações comunitárias étnicas. In: Economia e sociedade. Brasília: Ed. UnB, 1994. p.267-277.

${ }^{18}$ Circular aos Presidentes de Província. Ms. AN. Série Agricultura, JA7-4, fl.38.

${ }^{19}$ Ms. AN APERJ.PP col.115, dossiê 312, Pasta 1, n.3.

${ }^{20}$ Ms. APERJ P.P. Col.32,dossiê 118. Pasta 1.

${ }^{21}$ Ms. AN Série Agricultura, IA7 -1, fl 70v.

${ }^{22}$ Ms. AN série Agricultura, IA7-1, fl.78v.

${ }^{23}$ OLIVEIRA, Maria Rosalina. Relação de Documentos sobre a Igreja de São Lourenço dos Índios, 2000, inédito; Depoimento de Maria do Carmo Pinto Rodrigues e Gilda Pinto Rodrigues a Yohana Freitas, Marília dos Santos e Tarso Vicente, dez. 2003. Pesquisa realizada como exercício didático do curso de História Oral. MATOS, Hebe. Projeto: Cidade de Memórias - São Lourenço dos Índios e a cidade de Niterói. Niterói (RJ), Laboratório de História Oral e Imagem/LABHOI/UFF.

Artigo recebido em 20 de junho de 2012. Aprovado em 1o de setembro de 2012. 